\title{
REVIEW
}

\section{THE EFFECT OF ANTIHYPERTENSIVE THERAPY ON HUMAN SEXUALITY}

\author{
Břegová Bohdana ${ }^{1,2}$, Yvetta Vrublová ${ }^{2}$ \\ ${ }^{1}$ Internal medicine, University Hospital Ostrava, Czech Republic \\ ${ }^{2}$ Department of Nursing and Midwifery, Faculty of Medicine, University of Ostrava, Czech Republic
}

Received February 9, 2015; Accepted March 31, 2015. Copyright: This is an open access article distributed under the terms of the Creative Commons Attribution International License (CC BY). http://creativecommons.org/licenses/by/4.0/

\begin{abstract}
Aim: The aim was to analyse the effect of antihypertensive therapy on incidence of sexual dysfunction in patients with arterial hypertension. Design: a review study. Methods: In the period from 2000 to 2015 we searched licensed and freely available electronic databases: CINAHL EBSCOhost, ProQuest, Pubmed and Medline for relevant recherches of Czech and foreign sources. We set the following criteria: a study of least 100 participants and a minimum six-month follow-up. We excluded experimental and vaguely defined studies. From a total of 123 searches, 45 articles met the criteria. A review includes a total of 15 studies, six studies with a control group of healthy individuals, two cohort studies, six randomized trials and one case study with a control group. Results: The study analysis showed that beta-blockers and thiazide diuretics are the most detrimental in terms of incidence of sexual dysfunction. Angiotensin II receptor antagonists and angiotensin-converting enzyme inhibitors have a neutral or beneficial effect. Conclusion: The review article deals with the issue of patients' sexuality, focusing on the potentially negative effect of antihypertensive therapy on sexual function. Current scientific findings suggest that antihypertensive therapy increases the risk of occurence of sexual dysfunction. Professional literature is more dedicated to the incidence of male sexual dysfunction, especially erectile dysfunction, than with female sexual dysfunction.
\end{abstract}

Keywords: hypertension, antihypertensive therapy, sexual function, sexuality, sexual dysfunction.

\section{Introduction}

Life satisfaction is conditioned by physical and mental health. Contemporary society at the beginning of the third millennium is characterized by lifespan prolongation, i.e. an aging population and an increase in cardiovascular diseases. Arterial hypertension is considered to be one of the most common diseases of the cardiovascular system. Due to its high occurrence in the population, the issue of this disease has become very topical (Berková, Berka, Topinková, 2014 , p. 5-11). Sexuality is an important human need, that is everybody' $s$ right and an integral part of their personality (Šrenkel, 2013, p. 211). It is also a criterion that determines individuals' subjective satisfaction and affects each person's perception and feelings (Vique et al., 2006, p. 18). According to the Sexual Health and Overall Wellness Survey (the SHOW), conducted in nine European countries, sex is one of the highest priorities in $67 \%$ men and $57 \%$ women (Weiss, 2011, p. 3).

Corresponding author: Bohdana Břegová, Internal medicine, University Hospital Ostrava, 17. listopadu 1790, OstravaPoruba, Czech Republic, email: bohdana.bregova@fno.cz.
The prominent Czech sexologist, professor Zvěřina, (2010, p. 339) reports that sexual dysfunction (SD) is a disorder of sexual performance, characterized by insufficiency of one or more physiological components of sexual behaviour. Antihypertensive drugs are often discussed in connection with their negative effects on erectile function (Doumas et al., 2006, p. 2387-2392). A comprehensive German TRANSCEND, PRoFESS and ONTARGET metaanalysis conducted in 2005-2010, in which patients were followed for up to five years, dealt with the problem of the effects of drugs on erectile dysfunction (ED). This study showed that only thiazide diuretics and older, in particular nonselective beta-blockers, induce erectile dysfunction (Bultas, Karetová, 2014, p. 287). Centrally acting alpha agonists and diuretics are involved in the deterioration of sexual function, and aldosterone receptor antagonist diuretic spironolactone is associated with ED and gynaecomastia (Conaglen, Conaglen, 2013, p. 42-46). In addition, the evidence available also suggests possible adverse effects of hypertension treatment on female sexual function. Doumas et al. (2006, p. 2387) point out that the prevalence of female sexual dysfunction (FSD) in women with essential hypertension versus 
normotensive women depends on the degree of hypertension, age and duration of antihypertensive treatment. There is a higher prevalence of SD in hypertensive women than in normotensive ones (Ma et al., 2011, p. S9; Martelli et al., 2012, p. 439). Women may experience a decrease in or absence of libido, inability to achieve orgasm (Steinke, 2005, p. 40-50) and a decrease in vaginal lubrication (Šrámková, 2013, p. 86).

\begin{abstract}
Aim
The aim was to analyse the effect of antihypertensive therapy on incidence of SD and to find an association between antihypertensive therapy and SD, using relevant data from licensed and freely available electronic databases.
\end{abstract}

\section{Methods}

We chose a sensitive issue focusing on patients' intimate life with the aim of mapping the effects of antihypertensive therapy on individuals' sexual function and changes in sexuality which occur in patients treated for hypertension.

\section{Eligibility criteria}

The selection criteria chosen were: a study involving at least 100 participants and a minimum six-month follow-up. From the beginning we excluded studies which focused on evaluating the effects of drugs conducted by pharmaceutical companies, and experimental or vaguely-defined studies. We gradually excluded studies as recommended by PRISMA (see Scheme 1). From a total of 123 searches, 45 articles met the criteria.

\section{Sources}

Relevant data were used from licensed and freely available electronic databases: CINAHL EBSCOhost, ProQuest, Pubmed and Medline.

\section{Search}

The keywords 'hypertension', 'antihypertensive therapy', 'sexuality', and 'sexual dysfunction' were set as criteria for searching relevant sources in the time period 2000-2015.

\section{Study selection and data analysis}

The review includes a total of 15 studies: six studies conducted with a control group of healthy individuals, two cohort studies, six randomized trials, and a case study with a control group. There were eight studies on male sexual dysfunction (MSD) and seven studies on female sexual dysfunction (FSD). A total of 5,880 participants were included in the evaluated studies.

\section{Results and discussions}

In professional, mainly foreign publications, considerable attention is paid to the relationship between antihypertensive therapy and SD. Chronic disease such as hypertension, or its pharmacotherapy, affects patients' sexual function (Steggall, 2007, p. 49-56). The main determinants involved in SD, both in men and women, are hypertension, age and antihypertensive therapy. Occurence of SD is more frequent in hypertensive patients than in normotensive individuals (Manolis, Doumas, 2008, p. 2,074-2,084, Manolis, Doumas, 2012, p. 285-292). Sexuality disorders or SD in connection with hypertension treatment have subjective and objective characteristics. Subjective symptoms include problems with erections, or ejaculation, and objective symptoms include the strain on relationships with a partner (Sovová, Řehová, 2004, p. 76). In men, the side effects lead to a decrease in or loss of libido, erectile dysfunction, priapism, and premature or retrograde ejaculation. Women may experience a decrease in vaginal lubrication, low or absent libido and an inability to achieve orgasm (Steinke, 2005, p. 40-50).

From the searched literature, we included a total of 15 clinical studies in our review, (characterized in detail in Tab. 1 and Tab. 2) with a total of 5,880 participants, of whom 1,870 were women and 4,010 were men. Participants were followed up for at least six months. Standardized measuring scales and questionnaires were used in a total of nine studies. The most frequent measuring instrument was the International Index of Erectile Function (IIEF-5). Six clinical studies examined the effect of beta-blockers on sexual function; a total of five clinical studies examined the effect of pharmacologic antagonists angiotensin II; one study examined the effect of calcium channel blockers; and one study dealt with the effect of thiazide diuretics on occurrence of SD. The analysis of results shows that out of 15 clinical studies, 14 studies confirmed the negative effects of antihypertensive therapy or the treatment of the underlying disease (arterial hypertension) on participants' sexual function and only one clinical study showed a neutral or positive effect of treatment on prevalence of SD.

According to results of a randomized trial by Okeahialam and Obeka (2006, p. 638-640), in which a control group of normotensive participants was included, thiazide diuretics cause a higher prevalence of FSD, particularly in terms of decreased sexual desire. A total of five studies investigated which drug category of antihypertensive therapy results in a higher prevalence of SD. They evaluated beta- 
blockers and angiotensin II antagonists. The comparison showed a deterioration in male sexual activity caused by beta-blockers (Fogari et al., 2001, p. 27-31, Fogari et al., 2002, p. 77-80) and a reduction in female sexual desire (Fogari et al., 2004, p. 77-81). The opposite result was found in a randomized trial by Yang et al. (2013, p. 235-241), in which beta-blockers did not increase occurrence of SD. None of the five randomized trials indicate a higher prevalence of SD or a higher occurrence of ED due to treatment with angiotensin II antagonists.

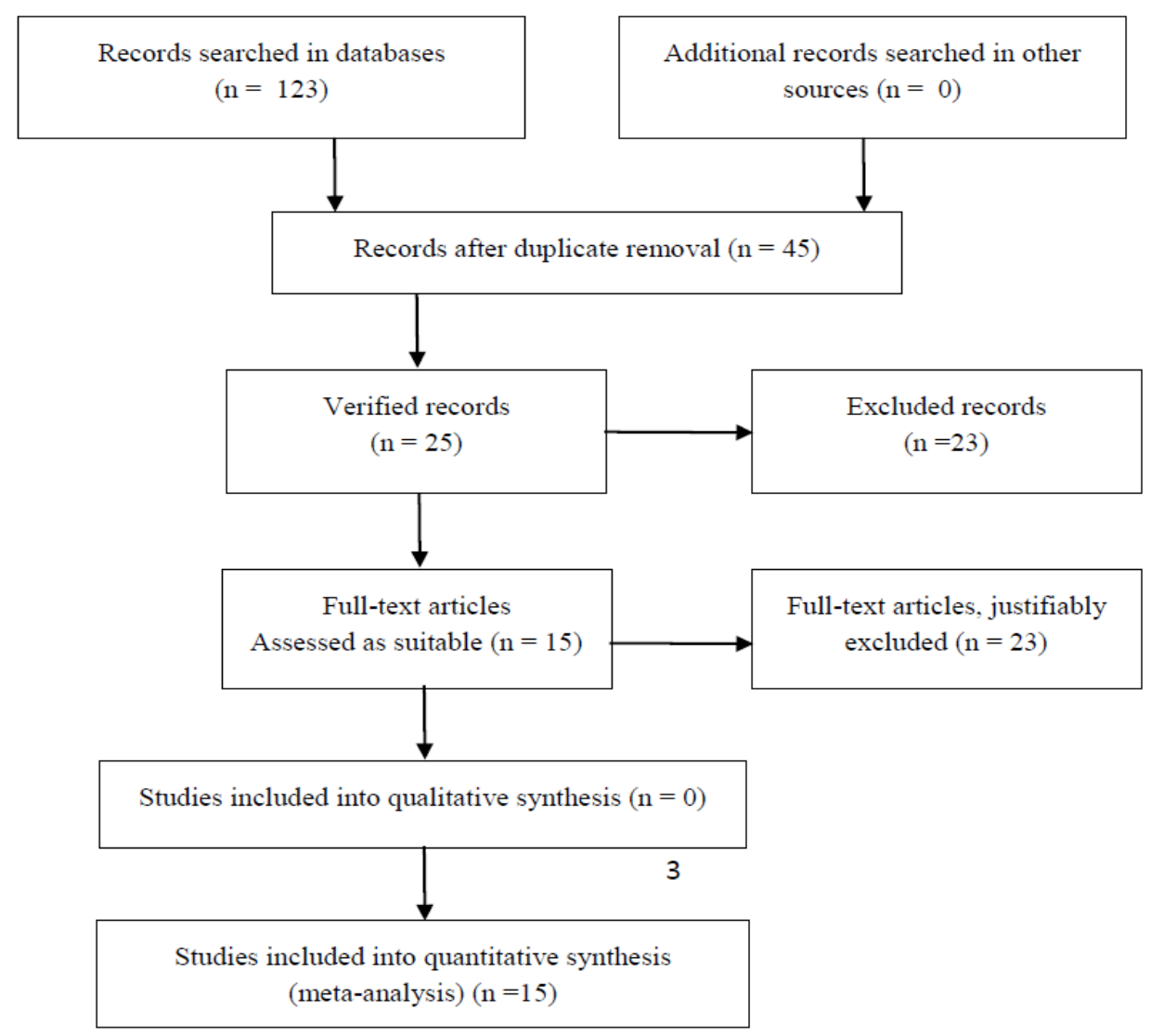

Scheme 1 Flowchart - PRISMA recommendation

\section{Results of occurrence of $S D$}

An analysis of the searched sources (Tab. 1) suggests that antihypertensive therapy adversely affects participants' sexual function. Doumas et al. (2006, p. 2387-2392) point out that the prevalence of FSD in women with essential hypertension versus normotensive women depends on the degree of hypertension, age, and duration of antihypertensive treatment. Their conclusions are based on a study conducted on a population of active women using the Female Sexual Function Index (FSFI). The results showed that out of a total of 417 women (216 hypertensive women and 201 non-hypertensive women), SD occurred in $42 \%$ hypertensive women and in 19\% normotensive women. The study concluded that there is a higher occurrence of FSD in women with essential hypertension compared with normotensive women (Doumas et al., 2006, p. 2387). There is a higher prevalence of SD in hypertensive women, in particular decreases in vaginal lubrication and problems achieving orgasm (Duncan et al., 2000, p. 640-647). Kütmec and Yurtsever (2011, p. 56-63) examined sexual function in women with hypertension, which is classified as a chronic disease and is said to be an important factor affecting SD due to physiopathological changes in the vascular endothelium. An experimental study included 71 hypertensive women not suffering from any other chronic disease. A control group consisted of 85 healthy married women. SD occurred in $90 \%$ women with hypertension and in $41 \%$ healthy women. It was also found that prevalence of SD increases with age, but with higher education and income female sexual problems decrease (Ma et al., 2011, p. S9). The results of the evaluation of SD using FSFI in 160 hypertensive and 50 normotensive women show that FSD is more common in women with essential hypertension. 
Table 1 Characteristics of clinical studies in relation of hypertension and antihypertensive therapy to prevalence of FSD

\begin{tabular}{lllll} 
Source, year & Aim & Number of participants & Method & Results \\
\hline Doumas et & To find the effect of & Data from 417 women, & A study with a & A significantly higher occurrence \\
al. (2006) & $\begin{array}{l}\text { beta-blockers on } \\
\text { prevalence of FSD. }\end{array}$ & $\begin{array}{l}\text { of whom 216 were } \\
\text { treated with arterial } \\
\text { hypertension and } 201\end{array}$ & $\begin{array}{l}\text { control group, using } \\
\text { of SD (p }<0.001) \text { in women with } \\
\text { arterial hypertension. }\end{array}$
\end{tabular}

Duncan et al. To determine effect (2000) of antihypertensive therapy on prevalence of FSD.

Duncan et al. To examine the effect (2001) of antihypertensive therapy on prevalence of FSD.

Fogari et al. (2004)

\section{Kütmec, Yurtsever (2011)}

Ma et al. (2011)

Okeahialam, To examine female Obeka (2006) of two drug categories, angiotensin II antagonists and betablockers.

\section{To find a significant} difference in prevalence of SD due to antihypertensive therapy in women with arterial hypertension in comparison with a control group.

To establish possible adverse effects of antihypertensive therapy on occurrence of SD.

sexuality, focusing on on the effect of

\section{hypertension and 201}

were normotensive.

To compare the effect thiazide diuretics on occurrence of SD.
3,312 medical records were examined, a total of 211 women, of whom 104 with arterial hypertension and 107 normotensive women were included into the study.

Data from 640 women.

A study wih a control group. A questionnaire with 47 items and a telephone interview. Statistical data processing using ANOVA at the level of significance 0.05 .

A study with a control group of healthy women, using 64-item SAQ.

Data from 120 women.

A randomized trial.

Data from 156 women, of whom 71 were treated for arterial hypertension and 85 were normotensive.

A study with a control group of healthy women.

Data from 210 women, of whom 160 were treated for arterial hypertension, and 50 were normotensive.

Data from 116 women. A study with a control group of healthy women.

A cohort study, using FSFI.
Hypertensive women, irrespective of the type of therapy, reported, in direct correlation with age, a decrease in vaginal lubrication, less frequent orgasm and more frequent pain in comparison with normotensive women.

The study confirmed a higher occurrence of SD in premenopausal women with arterial hypertension, especially a decrease in vaginal lubrication and problems with orgasm . In beta-blockers (atenolon) a significantly higher prevalence of SD was established in postmenopausal women (13.5\%), especially in the area of decreased sexual desire.

The study confirmed a higher prevalence of SD in women with arterial hypertension (90\%) and in normotensive women (40\%).

The Chinese cohort study confirmed a significant result ( $\mathrm{p}$ $<0.001$ ), confirming a higher prevalence of FSD with arterial hypertension in $60.4 \%$ compared with normotensive women (26\%).

In women with arterial hypertension, $30.8 \%$ occurrence of SD was found in comparison with a control group of healthy women with $4.7 \%$. Decreased sexual desire was the most common problem.
Fogari et al. (2004, p. 77-81) published a study examining the effect of treatment with valsartan and atenolol on the sexual behaviour of 120 menopausal women, aged 51-55, diagnosed with hypertension.
After 16 weeks of treatment they were asked questions from a ten-item self-assessment, covering aspects of desire, orgasm and coital activity. The results showed significant increase in sexual desire in 
women treated with valsartan. The result of another randomized trial on evaluation of SD using FSFI, evaluated after 24 and 48 weeks of treatment with felodipine in combination with irbesartan, showed improvement of sexual function in the items of arousal and orgasm. Occurrence of SD also increased with age (Ma et al., 2011, p. S9). A Nigerian study focusing on the potential negative effects of thiazide diuretics on the occurrence of SD did not confirm a statistically significant occurrence of SD in hypertensive women compared with a control group of healthy individuals (Okeahialam, Obeka, 2006, p. 638-640).

\section{The results of occurrence of MSD}

Tab. 2 describes the studies searched which investigate the effect of antihypertensive therapy on MSD. Mittawae et al. (2006, p. 575-578) examined patients' health status using IIEF-5 with an emphasis on hypertension and the assessment of their sexual function. Of 800 patients, with a mean age of 59.2, $739(92 \%)$ had regular sexual activity once or twice a week. Of these, $346(44 \%)$ were diagnosed with ED. The results showed that the presence and treatment of hypertension may increase ED. The following year, Bener et al. (2007, p. 870-878) conducted a Qatari study from May to October. A total of 425 participants with hypertension, aged 3075 , were selected for this study. Of these, 296 (74\%) participants agreed to be included in the study. The mean age was 54.8. Sexual function was assessed using IIEF, and ED occurred in $66 \%$ of patients. ED occurred in 196 (66.2\%) of the 296 participants with hypertension, while in the control group of healthy individuals, ED was reported in $71(23.8 \%)$ men out of a total of 298 participants. In participants with hypertension, $25 \%$ participants suffered severe ED, $29.1 \%$ moderate ED and $12.1 \%$ mild ED. Percentages of different domains of sexual activity were very significant, with a higher risk in hypertensive patients than in normotensive ones ( $p$ < 0.001 ). The results of the study showed that ED is more common in patients with antihypertensive therapy and that the frequency and severity of ED increases with age. The aim of a cohort study by Huang et al. (2014, p. e92794) was to assess erectile function in 1,531 Chinese men aged 40 to 80, classified as asexual and to further analyse the specific reasons for this condition. The conclusion of the study showed a higher prevalence of ED in $49.9 \%$ participants and prevalence of asexuality in $37.2 \%$ participants. Prevalence was significantly affected by participants' age, hypertension and diabetes mellitus. A Spanish study by Cuéllar de León et al. (2002, p. 521-526) aimed to define how consistent the inability to achieve or maintain an erection sufficient to permit satisfactory sexual intercourse was and how closely this was associated with hypertension. This multicenter study was conducted in primary care educational centers. A total of 512 participants with hypertension were included in the study, of whom five were excluded due to incomplete questionnaires. Prevalence of ED in hypertensive patients was evaluated using IIEF-5. The study analysed factors associated with ED which were in direct relationship with disease and ED. Participants' mean age was 63.36 (the age range was 30-86). The prevalence of ED was $46.5 \%$. No statistically significant occurrence of ED was established with age, but a high occurrence of ED was found in patients with hypertension. In the same year, another Spanish study was conducted by Guirao Sanchéz et al. (2002, p. 290-296), which reached a similar conclusion, showing hypertension to be the main indicator of ED in $33.6 \%$. The aim of a prospective, randomized study by Yang et al. (2013, p. 235-241) on 218 male participants was to establish whether the combination of calcium channel blockers with either angiotensin II blocker or beta-blockers could have similar effects on sexual function in hypertensive men. No statistically significant difference was found in occurrence of ED before and after the treatment in the two combination therapies. The results of the study even suggest that the combination of angiotensin converting enzyme inhibitors (ACEI) with angiotensin II may contribute to increased male sexual desire. The aim was to answer the question of whether antihypertensive therapy adversely affects sexual function and sexual life in men and women with arterial hypertension. A synthesis of all available data from clinical studies indicate that some studies confirm obvious side effects of antihypertensive therapy on sexual function, while others suggest the opposite. An analysis of the results did not reveal any negative effects of calcium channel blockers on sexual function. In fact, the results suggest the positive effects of this drug category on sexual function, namely increased sexual desire. Neither do ACEI cause a higher prevalence of SD. On the other hand, beta-blockers and thiazide diuretics have a significant negative impact on sexual function. A higher prevalence of SD was proved in these two drug categories. Men treated with beta-blockers (carvedilol, atenolon) report a decrease in sexual activity (Fogari et al., 2001; p. 27-31; Fogari et al., 2002 , p. 77-80). The results of clinical research are unambiguous: beta-blockers have a negative impact on human sexuality and contribute significantly to the occurrence of SD. 
Table 2 Characteristics of clinical studies in relation of hypertension and antihypertensive therapy to prevalence of MSD

\begin{tabular}{|c|c|c|c|c|}
\hline Source, year & Aim & $\begin{array}{l}\text { Number of } \\
\text { participants }\end{array}$ & Method & Results \\
\hline $\begin{array}{l}\text { Bener et al. } \\
\text { (2007) }\end{array}$ & $\begin{array}{l}\text { To determine occurrence of ED, } \\
\text { its severity or to find other SD } \\
\text { in hypertensive and } \\
\text { normotensive Qatari men. }\end{array}$ & $\begin{array}{l}\text { Data from } 594 \\
\text { men (age } \\
\text { range } 30-75) \text {. } \\
\text { A total of } 296 \\
\text { men were } \\
\text { treated for } \\
\text { hypertension } \\
\text { and } 298 \text { were }\end{array}$ & $\begin{array}{l}\text { A case study with } \\
\text { a control group } \\
\text { using IIEF. }\end{array}$ & $\begin{array}{l}\text { Of the } 296 \text { patients with hypertension, } 196 \\
(66.2 \%) \text { suffered from ED. Of } 298 \\
\text { normotensive men, } 71(23.8 \%) \text { reported ED. } \\
\text { A total of } 25 \% \text { hypertensive men suffered } \\
\text { from severe ED, } 29.1 \% \text { had moderate ED } \\
\text { and } 12.1 \% \text { had mild ED. The frequency and } \\
\text { severity of ED increased with age. }\end{array}$ \\
\hline
\end{tabular}

\section{Cuéllar de \\ León et al. (2002)}

Fogari et al. (2001)

\section{Fogari et al.} (2002)
To define how consistent the inability to achieve or maintain an erection sufficient for satisfactory sexual intercourse is and how closely SD is associated with hypertension. To find the effects of two pharmacological preparations: valsartan (angiotensin II. antagonist) and carvedilol (a beta-blocker) on sexual activity in men treated with hypertension in comparison with a control group of normotensive men.

To compare the effects of valsartan (angiotensin II antagonist) and of atenolol (beta-blocker) on sexual activity in newly diagnosed, previously untreated men with essential hypertension.

To find prevalence of ED and to analyze the specific reasons for this condition.

Mittawae et al. (2006)
To evaluate prevalence of ED, its severity and to find other sexual functional domains.
Guirao Sánchez et al. (2002)

Yang et al. (2013)
To identify factors associated with occurrence of ED.

To establish whether the combination of calcium channel blockers with either angiotensin II blocker or beta-blockers can have similar effects on sexual function in hypertensive men.
Data from

1,531 Chinese men, age range 40-80.

Data from 800 Egyptian men treated for hypertension. The mean age was $59.2+/-$ 2.3 yrs (age range 28-75). Data from 125 men.

A randomized trial, using IIEF5.

\section{A randomized} study, participants were also administered a placebo. The statistical significance level was 0.05 .

A cohort study, using IIEF-5.

A randomized trial, using IIEF5.

Data from 218 A randomized men.
Deterioration in sexual activity due to carvedilol (beta-blocker).

The results suggest the negative effect of atenolol on sexual activity. Beta-blocker therapy significantly reduced sexual activity (from 6.0 sexual episodes/month to 4.2 sexual episodes/month $(\mathrm{p}<0.01)$ compared with placebo. Valsartan therapy caused a slight increase in male sexual activity. From a total of 5.8 sexual episodes/month to 7.4 sexual episodes/month $(\mathrm{p}=0.058)$ compared with a placebo.

A higher prevalence of ED in $49.9 \%$ participants and prevalence of asexuality in $37.2 \%$ participants were found. Higher prevalence was significantly affected by participants' age, hypertension and diabetes mellitus.

Of a total of 800 men, $739(92.3 \%)$ had regular sexual activity (once or twice per week) and 346 (43.2\%) suffered from ED. Of the total number of men, $40(5 \%)$ had mild ED, $96(12 \%)$ moderate, and 210 (26.2\%) severe ED. A highly statistically significant correlation between the duration of hypertension and mild ED was found. $33.6 \%$ men with hypertension suffered from ED.

A higher prevalence of ED was not found. The results suggest that the drugs felodipine (ACEI) and irbesartan (angiotensin II blocker) may be beneficial to sexual desire in hypertensive men, rather than a combination of felodipine (ACEI) and metoprolol (beta-blockers). 
Furthermore, it was found that antihypertensive therapy has a significant impact on higher prevalence of ED (Guirao Sánchez et al, 2002, p. 290-296; Cuéllar de León et al., 2002, p. 521-526; Bener et al., 2007, p. 870-878; Huang et al., 2014, p. e92794). The opposite result regarding the effects of antihypertensive therapy on occurrence of ED is reported by Yang et al. (2013, p. 235-241). The fact that occurrence of SD correlates with age also attracted attention. A clinical randomized trial by Huang et al. (2014, p. e92794) included, in our opinion, sufficient participants to establish a statistically significant result. A relatively large number of the clinical studies searched included a control group of healthy subjects with which to compare the significance of occurrence of SD. Based on the data from clinical studies, we found that there is a higher prevalence of SD in women with arterial hypertension compared to normotensive women (Doumas et al., 2006, p. 2387-2392; Kütmec, Yurtsever, 2011, p. 56-63; Ma et al., 2011, p. S9). At present, there still remain many open and unanswered questions regarding occurrence of SD in men and women with arterial hypertension

\section{Conclusion}

Chronic diseases, which include arterial hypertension, can restrict individuals' life in some ways and reduce life satisfaction. Current scientific findings suggest a higher risk of occurrence of SD during antihypertensive therapy. The literature shows that SD brings psychological problems, somatic complaints, emotional stress and social isolation. It causes relationship problems, significantly impairs the stability of a marriage or cohabitation and, not least, it reduces individuals' life satisfaction (Pastor et al., 2008, p. 1). We closely examined human sexuality and, based on analysis of the results, have come to significant conclusions, one of which is the fact that men and women show a statistically significant difference in occurrence of SD due to antihypertensive therapy. This could be explained from several interrelated perspectives. The literature states age, menopause, antihypertensive therapy and duration of treatment of arterial hypertension. Hypertensive men have the greatest difficulty achieving erection and the most problems with sexual activity. Women treated with antihypertensive therapy experience a reduced desire for sexual activity (libido), as well as problems with vaginal lubrication and attainment of sexual arousal. Furthermore, we can state that occurrence of SD correlates with age. We should not lose sight of the fact that quality health care specifies that we should do the right things at the right time to the right people and thereby achieve the best possible results under current conditions (Gladkij et al., 2003, p. 364). Sexuality, as a basic human need, falls into the realm of nursing, where nursing professionals' knowledge of the potential negative effects of antihypertensive therapy may lead to more targeted patient education and, in turn, greater patient satisfaction.

\section{Ethical aspects and conflict of interest}

We declare that the research conducted within this review study does not constitute any conflict of interest and that the results were processed in compliance with ethical standards.

\section{Author contribution}

Concept and design (BB, YV), data collection (BB), data analysis and interpretation (BB, YV), drafting the manuscript (BB), supervision (YV), critical correction of the manuscript (BB, YV).

\section{References}

Bener A, Al-Ansari A, Al-Hamaq AO, Elbagi IE, Afifi M. Prevalence of erectile dysfunction among hypertensive and nonhypertensive Qatari men. Medicina (Kaunas). 2007;43(11):870-878.

Berková M, Berka Z, Topinková E. Problematika arteriální hypertenze $\mathrm{v}$ otázkách a odpovědích. Geriatrie $a$ gerontologie. 2014;3(1):5-11. (in Czech)

Bultas J, Karetová D. Farmakoterapie erektilní dysfunkce kde jsme a kam směrujeme. Kardiologická Revue - Interní Medicina. 2014;16(4):281-287. (in Czech)

Conaglen HM, Conaglen JV. Drug - induced sexual dysfunction in men and women. Australian prescriber. 2013;36(2):42-46.

Cuéllar de León AJ, Ruiz GV, Casmos GJC, Pérez HP, Brotons MB. Prevalence erectile dysfunction in patients with hypertension. Journal of Medicina Clinica (Barcelona). 2002;119(14):521-526.

Doumas M, Tsiodras S, Tsakiris A, Douma S, Chounta A, Papadopoulos A, Kanellakopoulou K, Giamarellou H. Female sexual dysfuncion in essentials hypertension: a common problem being uncovered. Journal of Hypertension. 2006;24(12):2387-2392.

Duncan LE, Lewis C, Jenkins P, Pearson T. Does hypertension and its pharmacotherapy affect the quality of sexual function in women? American Journal of Hypertension. 2000;13(6):640-647.

Fogari R, Zoppi A, Poletti L, Marasi G, Mugellini A, Corradi L. Sexual activity in hypertensive men treated with valsartan or carvedilol: a crossover study. American Journal Hypertension. 2001;14(1):27-31.

Fogari R, Preti P, Derosa G, Marasi G, Zoppi A, Rinaldi A, Mugellini A. Effect of antihypertensive treatment with valsartan or atenolol on sexual activity and plasma testosterone in hypertensive men. The Europe Journal of Clinical Pharmacology. 2002;58(3):77-80.

Fogari R, Preti P, Zoppi A, Corradi L, Pasotti C, Rinaldi A, Mugellini A. Effect of valsartan and atenolol on sexual 
behavior in hypertesive postmenopausal woman. American Journal Hypertension. 2004;17(1):77-81.

Gladkij I et al. Management ve zdravotnictví. 1. vyd. Brno: Computer Press; 2003. (in Czech)

Guirao Sánchez L, García-Giralda Ruiz L, Sandoval Martínez C, Mocciaro Loveccio A. Erectile dysfunction in primary care as possible marker of health status: associated factors and response to sildenafil. Atención Primaria. 2002;30(5):290296.

Huang YP, Chen B, Ping P, Wang HX, Hu K, Yang H, Zhang T, Feng T, Jin Y, Han YF, Wang YX, Huang YR. Asexuality development among middle aged and older men. Plos One. 2014;9(3):e92794.

Kütmec C, Yurtsever S. Effects of sexual function of essential hypertensions in women. European Journal of Cardivascular Nursing. 2011;10(1):56-63.

Ma R, Yu J, Xu D, Yang L, Lin X, Li X, Chang P, Feng Z, Guo X, Bai F. The relationship between oxidative stress and sexual dysfunction in female patients with hypertension. Journal of Cardiology. 2011;152(1):S9.

Manolis A, Doumas M. Sexual dysfunction: the 'prima ballerina' of hypertension-related quality-of-life complication. Journal of Hypertension. 2008;26(11):2074-2084.

Manolis A, Doumas M. Antihypertensive treatment and sexual dysfunction. Current Hypertension Research. 2012;14(4):285-292.

Martelli V, Valisella S, Moscatiello S, Matteucci C, Lantadilla C, Costantino A, Pelusi G, Marchesini G, Meriggiola MC. Prevalence of sexual dysfunction among postmenopausal women with and without metabolic syndrome. Journal of Sexual Medicine. 2012;9(2):434-441.

Mittawae B, El-Nashaar AR, Founda A, Magdy M, Shamloul

R. Incidence of erectile dysfunction in 800 hypertensive patients: a multicenter Egyptian national study. Urology. 2006;67(3):575-578.

Okeahialam BN, Obeka NC. Sexual dysfunction in female hypertensive. Journal of National Medical Associattion. 2006;98(4):638-640.

Pastor Z, Zámečník L, Chaloupka V, Červený R, Hollý M, Čechurová D. Doporučený diagnostický a léčebný postup pro všeobecné praktické lékaře. Nadační fond praktik; 2008 [cited 2014 Aug 12]. Available from: http://www.svl.cz/files/files/Doporucene-postupy-2008-

2012/erektilni-dysfunkce.pdf/ (in Czech)

Sovová E, Řehová J. Kardiologie pro obor ošetřovatelství. 1. vyd. Praha: Grada; 2004. (in Czech)

Steinke EE. Intimaci need and chronic illnes: Strategies for sexual counseling and self-management. Journal of Gerontological nursing. 2005;31(5):40-50.

Steggall MJ. Erectile dysfunction: fysiology, cause and patient management. Nursing standard. 2007;21(43):49-56.

Šrámková T. Poruchy sexuality u somaticky nemocných a jejich léčba. 1. vyd. Praha: Grada Publishing; 2013. (in Czech)

Šrenkel J. Sexuální výchova a protokol sexuality v domovech sociálních služeb. In: Mitlohner M, Prouzová Z, editors. 21. Celostátni kongres k sexuálni výchově v České Republice, Pardubice, 2013, Sbornik referátů. Ostrava: CAT; 2013. s. 210-221. (in Czech)

Vique $\mathrm{J}$ et al. Zdravý sexuální život. Čestlice: Rebo Production; 2006. (in Czech)

Yang L, Yu J, Ma R, Zhao F, Lin X, Liu P, Hu H, Bai F. The effect of combined antihypertensive treatment (felodipine with either irbesartan or metoprolol) on erectile function: a randomized controlled trial. Cardiology. 2013;125(4):235241. 